\title{
'Laying out a Model Village': George Gushue-Taylor and Missionary Leprosy Work in Colonial Taiwan
}

設立示範村 : 戴仁壽與日治時期臺灣的癩病傳教醫療

Wen-Ji Wang 王文基 (國立陽明大學 科技與社會研究所)

Received: 24 August 2006 / Accepted: 22 August 2007 /

Published online: 11 December 2007

(C) National Science Council, Taiwan 2007

\begin{abstract}
At a time when colonial governments were reluctant to launch comprehensive anti-leprosy programmes in the first half of the twentieth century, international charity organisations and medical missionary workers were keen on tackling this highly moralised disease. The same applied in colonial Taiwan under Japanese rule. Following the works of Michael Worboys, Sanjiv Kakar and others, the present study looks into the work of charitable and religious organisations through a historical account of the career of the Canadian leprologist Dr George Gushue-Taylor (1883-1954).
\end{abstract}

Chinese Abstract 近年來因捷運工程面臨拆遷的危險, 再加上台、韓籍癩病病 患於殖民時期被強制隔離而向日本政府求償等問題, 樂生療養院及癩病歷史 引發社會大眾高度興趣, 學界也多有研究。相較之下, 臺灣另一個癩病療養機 構樂山園的歷史, 以及西方傳教醫療在臺灣癩病防治上所扮演的角色, 迄今 認識尚嫌不足。本文運用一九二 $、 、 三 ○$ 年代教會檔案、樂山園創辦者戴仁壽醫 師的私人信函, 以及當時醫學圖書、期刊等文獻, 對樂山園的興建過程, 以 及初期經營的情況進行歷史研究。此外, 樂山園的創設與經營並非單純醫療宣 教士的個人行誼, 而應放在二十世紀初殖民公共衛生防治的發展, 以及傳教 醫學高度參與癩病防治的脈絡下討論。最後, 藉由戴仁壽對日治時期臺灣癩病 醫療與防治工作的觀察, 可清楚看出西方傳教醫學以及日本殖民醫學間的互 動。而他對日本殖民政府的批評, 或可修正日本殖民政府在台創設「普遍」且 「發達」的公共衛生設施此一傳統形象。

Keywords Leprosy · Colonial medicine · George Gushue-Taylor . The Mission to lepers

\footnotetext{
W.-J. Wang 王文基 (國立陽明大學 科技與社會研究所) (凶) Institute of Science, Technology, and Society, National Yang Ming University, 155, Sec. 2, Linong Street, Peitou, Taipei 11221, Taiwan e-mail: wjwang@cantab.net
} 
Leprosy, or Hansen's disease, has lately become a focus of attention in Taiwan. A plan to demolish a considerable part of the Lo Sheng Sanatorium (樂生療養院, or the Happy Life Sanatorium) at Hsin-Chuang, Taipei to house a Mass Rapid Transit maintenance depot has led to the possible forced eviction of hundreds of elderly patients from their homes. The controversies and strong opposition created by this governmental action have been generating fierce debates over the priority of heritage preservation and human rights versus community development. In addition, the compensation suits filed by former Taiwanese and South Korean leprosy patients against the Japanese government for compulsory segregation and violation of human rights during the colonial rule have perhaps wider implications. The resonances of the Japanese colonial legacy are clearly felt again in the East Asian societies. These recent developments have spurred intense public and scholarly interest in the history of the institution and that of the treatment of leprosy patients in general. Even though a number of historical, sociological, anthropological and architectural studies of Lo Sheng and its inmates have been published, ${ }^{1}$ the social concern of the matter seems unabated.

Compared with the mounting attention paid to this governmental leprosarium and its future development, little is known about another leprosy institution in Taiwan, the Presbyterian Happy Mount Leprosy Colony (樂山園), and missionary involvement in the anti-leprosy work. The present study intends to fill this gap by exploring the early history of the Colony, particularly its objectives and the philosophy as well as the practices of its management. Often marginalised during the Japanese colonial rule and in later historical accounts, Western colonial medicine in its missionary form in general and Happy Mount in particular had their specific roles to play in a rather awkward situation. It is the author's belief that in order to have a fuller picture of the history of leprosy treatment in colonial Taiwan, the relationship between governmental and missionary activities has to be properly examined. The observations made by Dr George Gushue-Taylor (戴仁壽, 1883-1954), the founder and first superintendent of Happy Mount, in the 1920s and 1930s also provide an excellent outsider's account of the Japanese colonial public health measures. Their analysis may help us to have a more nuanced understanding of the so-called 'medical achievements' during the colonial period.

There has been a growing historical interest in early twentieth-century colonial leprosy work. The disease's stigmatising status and the international attention it attracted in modern times has been related to the revival of Western imperial expansion since the late nineteenth century, the increasing missionary involvement during the same period, and the need to both police colonial subjects and reinforce racial segregation in the first half of the twentieth century (Gussow and Tracy 1970; Gussow 1989; Saunders 1989; Kipp 1994; Deacon 1994, 1996; Kakar 1996; Bashford and Nugent 2001; Worboys 2001; Bernabeu-Mestre and Ballester-Artigues 2004). Moreover, the influence of Michel Foucault's work can be seen in recent studies on the relationship between the management of leprosy institutions, the production of scientific knowledge, and the construction of modern citizenship in

\footnotetext{
${ }^{1}$ Just to name a few for example: Chen (2001, 2005), Fann (2005), Serizawa (2006), Pan (2005), Yen (2005).

型 Springer
} 
different colonial contexts (Vaughan 1991; Anderson 1998). The general impression is that most studies so far have concentrated on the analysis of the treatment and civic protocols of various colonial and missionary measures. Apart from studying modern medical activities and their cultural implications in colonial Taiwan, the present study also tries to explore the actual impact of these public health systems. Hopefully it will help us to learn more about the extent of the influence exerted by colonial medicine on the Taiwanese society at large. Nevertheless, some of the issues discussed in above-mentioned studies are extremely helpful in putting Happy Mount in a wider framework.

In the first decades of the twentieth century, the problem of leprosy drew attention from different sectors of the Taiwanese society. In 1900, five years after the island was ceded to Japan after the Chinese defeat in the Sino-Japanese war, the first census of lepers was conducted by the colonial government. With a population over three million, the estimated number of patients on the island was 810 (Fann 2001). As the census was conducted mainly by the police, the figure was highly questionable. In 1901, Taiyû Aoki, a physician working at the governmental Taihoku (Taipei) Hospital, reported that leprosy cases in Taiwan accounted for $0.95 \%$ of the whole outpatient population, which was eight times the rate in Japan proper. As the total leprosy population might have reached as high as 28,800 and the majority of cases were highly contagious, he recommended the instant establishment of leprosaria, both for compulsory segregation of lepers and for laboratory studies (Aoki 1901; Fann 2001). Even though actual figure of the patient population varied greatly between different evaluations, the risk posed by leprosy to public health remained a constant concern. During the 1910s and 1920s, plans for building leprosaria were proposed by Japanese doctors on several occasions and were supported by some Japanese and Taiwanese social elites (Nakamura 1931). The local community was also involved in the same campaign. For instance, a similar but smaller project of setting up a leper home for 50 patients was attempted by Longhua Hui (龍華會), a Buddhist sect, at Chia-Yi (嘉義), in 1920 (Anonymous 1920). In Taihoku, Ai-ai Roy (愛愛寮), a beggars' home founded by a Taiwanese philanthropist, had an isolation room for 5 lepers (Anonymous 1930).

Compared with the medical profession and other social sectors, the Japanese colonial government's response to the leprosy problem was slow and inadequate. At the turn of the century, the system of German state medicine was introduced by the Japanese into their newly gained colony of Taiwan as a major tool of government. With the combination of a sanitary police force and a centralised medical administration, the island was scheduled to be transformed from a so-called 'hotbed of tropical diseases' into an environment favourable for Japanese colonisation and exploitation. The Japanese prized themselves as governing by means of 'biological principle,' and yet the modern-minded colonial power had its priorities. 'Tropical acclimatisation' and the mental and physical competitiveness of the Japanese colonizers were always their top concerns (Fann 2005). Far into the 1930s, modern public medical and sanitary facilities were only available largely in areas where the Japanese community thrived, mainly major cities and the Eastern part of the island (Liu 2004). ${ }^{2}$ In addition, though also being a nation suffering seriously from leprosy,

\footnotetext{
${ }^{2}$ For medical system in colonial Taiwan, see also Lo (2002).
} 
the Japanese were not as concerned with the disease as they were with pressing epidemics like plague and malaria (Fann 2005). James L. Maxwell, a medical missionary who had previously worked in southern Taiwan, made this condition explicit in late 1924. 'In reply to the question as to what has been done in our district for the segregation and/or treatment of lepers. I have to say that nothing whatever has been done along these lines... The Government helps in no way with leper work as such. They give small annual gifts to our hospital work.'3

Partly because of social pressure and partly the new policy of 'Japanese extensionism' (內地延長主義: a policy treating Taiwan as an extension of Japan homeland instead of merely a colony), the Formosan Government began to introduce the then accepted tactic of compulsory segregation in its anti-leprosy enterprise in the late 1920s (Fann 2001). Common to the colonial context, public health policy planning did not however guarantee its immediate materialisation (Arnold 1994). Mainly due to the budget constraint for public health, plans for setting up three large Leper Settlements on the island had been discussed but no formal action was ever taken. ${ }^{4}$ The budget for building a governmental Isolation Hospital was finally approved in 1927, with the Leprosy Prevention Law of Taiwan passed two years later. The government's Happy Life Leprosy Hospital (or the 'Rakusei-in,' 樂生院) was not opened until December $1930 .^{5}$ It is noteworthy that, while the estimated number of Taiwanese leprosy cases in 1920s and early 1930s ranged from 1,084 to over 20,000, the newly opened Happy Life Hospital had only the facility for 100 permanent patients and 50 outpatients (Ishii 1931). Budget concern perhaps also explains some of the differences between national and colonial health policies. According to a Taiwan nichinichi shimpoo report in 1926, the principle of Taiwanese leprosy policy was, interestingly, not the compulsory segregation of all lepers but the provision of medical treatment for the willing but poor (Anonymous 1926b). ${ }^{6}$ Even for some contemporary observers, it was quite clear that the Formosan Government was behind Japan proper and Korea in launching a comprehensive leprosy prevention programme by 10-20 years (Miyahara 1919; Anonymous 1931a). ${ }^{7}$ Furthermore, the few Japanese clinics and doctors on the island did not welcome leprosy patients. ${ }^{8}$ Rev. A. Oltmans, Secretary in Japan of the American Mission to Lepers, observed in 1932 that, Japan-as a country advanced in modern civilisationshould have had done more in disease prevention. Nonetheless, 'the more enlightened a community or nation becomes, the more it is inclined to guard against exposure of its ugly sores (Oltmans 1933).'

\footnotetext{
${ }^{3}$ The Leprosy Mission International Archives (hereafter LMI) 118/5, James L. Maxwell, 'Lepers in Formosa,' n.d.

${ }^{4}$ LMI 118/5, W. M. Danner and George Gushue-Taylor, 'The Leper Problem in Formosa,' February 4, 1926.

${ }^{5}$ The Act on Leprosy Prevention was passed by the Japanese Diet in 1907. Two years later, 5 public leprosaria were established in Japan proper. See Sato and Narita (2003).

${ }^{6}$ The policy changed later on.

${ }^{7}$ LMI 118/5, George Gushue-Taylor to W. M. Danner, February 19, 1931.

${ }^{8}$ LMI 118/5, George Gushue-Taylor, 'Plans for Leprosy Work in Formosa' (around 1929). LMI 118/5, Robert B McClure to Mission to Lepers, August 5, 1929. There were however exceptions. For the treatment of Japanese and Formosan patients in the Governmental Taihoku Hospital, see Atsushi Miyahara $(1919,1921)$. For leprosy and racial hygiene in colonial Taiwan, see Fann (2001).
} 


\section{From Out-Patient Clinic to Leprosy Colony}

Due to both the Japanese reluctance to tackle leprosy at the island-wide level during the first half of the colonial rule and the seriousness of the problem for the local population, some leeway was created. Ever since the mid-nineteenth century, Western missionaries, realising the importance of modern medicine in spreading Christianity, were eager to provide humanitarian and medical aid to people in 'backward areas' (Worboys 2001). As Western colonial powers' interest in opening the Chinese market increased during the $1860 \mathrm{~s}$, missionary medicine was being introduced in Taiwan during the same period. Under the protection of their metropoles, Western physicians practising at trading ports and other itinerary medical missionaries gradually built up a loose network of medical and religious services ( $\mathrm{Fu} 2005)$. Moreover, because of the symbolic significance leprosy held for Christians, medical missionaries became the main source of voluntary work on the island, as indeed they did for many other places around the world. Local leprosy patients were treated in missionary hospitals in Shōka (彰化) and Tainan (台南) from the late nineteenth century onwards (Kato 1935; Li 1972). ${ }^{9}$

It should be added that these missionary activities might have had wider implications for the locals. Zachary Gussow, Rita Smith Kipp, Sanjiv Kakar and others have pointed out that the charity work and medical aid supplied by Western missionaries in the context of rising colonialism ran the risk of stigmatising leprosy patients again. Exaggerating the contagiousness of the disease and stressing on its biblical connections, 'mission societies added a parabolized moral status to an already existing secular stigma' (Gussow 1989; Kipp 1994). Leprosy patients became the most deplorable people on earth who needed their Christian caring. This evangelist and philanthropic use of leprosy often reinforced social control and exclusion (Bernabeu-Mestre and Ballester-Artigues 2004).

The most prominent figure in missionary leprosy work in Taiwan was Dr George Gushue-Taylor. Gushue-Taylor was born in Newfoundland and completed his medical training in London. He was a Fellow of the Royal College of Surgeons and briefly practiced in Harley Street and later at Dr. Barnardo's Homes for homeless boys in London. In 1925, the Presbyterian MacKay Memorial Hospital in Taihoku was reopened and Gushue-Taylor took up its superintendency. He had already treated leprosy patients while working in Tainan, at the south of the island, in the 1910s (Roland 1996). After noticing the leprosy problem in Taiwan (his estimation was from 3,000 to 4,000 cases), he started his own 'personal' anti-leprosy enterprise in 1925. An outpatient clinic was opened on Saturdays in Taihoku. ${ }^{10}$ As the number of patients at MacKay Memorial Hospital increased, the Mission to Lepers, a London-based international philanthropic organisation, offered to help. A leprosy dispensary was formally opened opposite the hospital in October 1927. For a period of time, Mackay hospital became the most important centre for leprosy treatment in

\footnotetext{
${ }^{9}$ LMI 118/5, George Gushue-Taylor, 'Happy Mount Leprosy Colony (Rakusanen), Formosa, Japan,' News Letter No. 6, May 1934.

${ }^{10}$ The Presbyterian Church of Canada Archives (hereaftger PCC) 101-H-28, George Gushue-Taylor, 'A Brief History of Anti-Leprosy Work in Taiwan,' December 27, 1953.
} 
Taiwan. In 1929, for example, its outpatient leprosy clinic treated 203 patients, and the total number of person-time reached 5,285 . $^{11}$

The cause for this new clinical optimism and other preventive measures was partly due to the improvement of laboratory techniques in the first decades of the twentieth century. Microscopic examination found that early cases were more contagious and therefore posed a more serious public health hazard than middle and late stage cases (Kakar 1996). The founding of a leprosy dispensary at Taihoku had also to do with the general use of chaulmoogra oil and its derivatives in the treatment during the period. With the rise of this new treatment, leprosy was no longer considered incurable. The treatment, however, was never deemed miraculous. Even in favourable cases, the whole process of treatment still took three to four years. In addition, it was still impossible to eradicate lepra bacilli from the human body completely. Partly because of this uncertainty, there was no standard method of treatment available at the time. According to a report of an international conference held in 1931, the method of treatment

will vary with the number and type of cases to be treated, and with the available personnel and facilities. It will also depend upon the political, geographical, and economic conditions of the community, as well as upon the attitude of the patients and of the general public towards the whole subject... While certain types and classes of patients may be adequately treated as out-patients, it will be apparent that cases requiring close supervision and those who are incapacitated should have institutional care (Anonymous 1931b). ${ }^{12}$

These regional differences were destined to generate conflicting anti-leprosy practices, a subject which will be explored shortly. According to Robert Cochrane, a contemporary authority on leprosy, the new treatment was of importance not because of its efficacy, but because the encouragement of early cases to seek medical attention allowed one to understand the disease better (Cochrane 1934). Furthermore, the adoption of the new treatment itself had enormous consequences on an institutional level. Previously, the work had mainly been carried out by amateurs out of compassion and a sense of religious calling. As the medical aspect of the anti-leprosy movement began to gain importance, the early twentieth century witnessed a shift toward greater involvement of medical professionals, especially those associated with missionary organisations (The Leprosy Mission 1974).

After touring around over ten countries and consulting leading leprologists in Asia, India, Africa, and the United States, Gushue-Taylor was not content with an outpatient leprosy clinic. His original plan of building a small leprosarium for 50 inmates was however repeatedly rejected by the Mission to Lepers. William Anderson, the General Secretary of the Mission, insisted that the project of a leper settlement was so massive and costly that it should be the responsibility of the Japanese Government. Instead, he urged Gushue-Taylor to concentrate his effort on the outpatient station work and on the supervision of the whole leprosy situation in Taiwan. Another problem is that, for Anderson, the relationship between the

\footnotetext{
${ }^{11}$ In the same year, the numbers of person-time of leprosy outpatients at Tainan and Shōka missionary hospitals were 1,520 and 220 respectively. See Ishii (1931).

${ }^{12}$ For difference in interpretation, see also Burnet (1931).

型 Springer
} 
governing body of the proposed leprosarium, the local church and the contributors abroad remained unclear. ${ }^{13}$ In addition, a number of specialists in India, China and Korea highly advocated the outpatient treatment of leprosy. ${ }^{14}$ Nevertheless, for Gushue-Taylor, as well as for like-minded leprologists at the time, the concern was a different one. While some pushed for more clinics and utilised hospitals and other institutions mainly for treating early cases and isolating highly contagious patients, an outpatient dispensary would be very likely to become a centre for the dispersal of the disease, rather than its cure. Moreover, 'essential adjuncts of efficient treatment such as exercise, ventilation of their rooms, proper food, hygiene of the skin, and other aspects as lepra reaction, cannot be supervised, corrected and treated.' ${ }^{15}$ Leprosaria were Gushue-Taylor's answer, since the cure consisted more in the improvement of the patient's bodily resistance and of his or her general standard of living (Muir 1936). In a word, what was actually needed was not regular chemical treatment for patients but the regulation of their daily lives. 'Out-patient treatment for infective cases of leprosy,' Gushue-Taylor further reckoned, 'is not in accord with modern methods in dealing with such an infective condition, and only conditions of poverty form the excuse for perpetuating in backward communities a situation intolerable in our home lands. ${ }^{, 16}$

\section{Work Therapy and the Civilising Mission}

Happy Mount Leprosy Colony was eventually opened on March 30, 1934 at Hachi-ri-sho, near Tamsui, Taihoku. There were twenty cottages in total, each housing 4 patients. The budget for construction and facility maintenance came from a variety of sources: the Formosan Government, the Empress Dowager of Japan, and donations both domestic and foreign. By the end of 1934, there were 24 patients. From 1935 to $1940,{ }^{17}$ the number of patients ranged from 42 to 69 . They were all Taiwanese, coming from different social classes, but mainly 'of lower working class, farm hands and day labourers (Gauld and Gauld 1939).'

The original name for the institution was 'Happy Mount Leprosy Hospital.' It was later changed into 'Happy Mount Leprosy Colony.' One of the reasons for the alteration was to distinguish the institution from the Governmental Leprosy Hospital. As Gushue-Taylor put it, 'what we want to build is not a hospital, but a village. Cottages are more like our homes, accommodating patients (Gushue-Taylor 1984).' The term, Leprosy Colony, derived from its specific function. At that time there were various types of leprosarium. Lazar houses, leper camps or asylums were designed to isolate lepers when they were deemed hopeless. Leper homes were established out of pity and provided housing for social outcasts. Leper hospitals designated the fact that leprosy was a treatable disease. In the early decades of the twentieth century, the

\footnotetext{
${ }^{13}$ LMI 118/5, W. H. P. Anderson to A. Oltmans, January 11, 1929. LMI 118/5, W. H. P. Anderson to George Gushue-Taylor, December 19, 1930.

${ }^{14}$ Danner and Gushue-Taylor, 'The Leper Problem in Formosa.'

${ }^{15}$ LMI 118/5, George Gushue-Taylor, 'Plans for Leprosy Work in Formosa,' n.d.

${ }^{16}$ LMI 118/5, Gushue-Taylor to W. H. P. Anderson, February 13, 1930.

${ }^{17}$ As the conflict of the Pacific war increased, the missionary work in Taiwan was forced to withdraw at the end of 1940 .
} 
importance of physical exercise and work therapy were stressed. Leper colonies or settlements were founded with the knowledge that 'long periods of treatment necessary for recovery must be spent under normal physical, mental, and social circumstances.' Medical facilities were provided in leprosaria of this kind, but 'the main stress is laid upon agricultural and industrial employment, as such occupations afford the atmosphere and conditions most important for control of the disease, and, in favourable cases, for recovery (Muir 1938).' So, for Gushue-Taylor, the reference to colony suggested that the aim of his institution was to "receive earlier cases to treat, arrest and return to their homes. ${ }^{18}$

George M. Kerr, the superintendent of Dichpali Colony in India, used a then familiar dictum to explain the importance of work in leprosy treatment: 'Faith-Oil-Work, but the greatest of these is Work (Kerr 1937).' R. M. Wilson, a medical missionary working in Korea, pointed out that leprosy colonies should be schools, teaching not only the importance of isolation and personal hygiene, but certain trades and occupations. Work had to be allocated to each patient, as '[a]n idle brain is the devil's workshop with the leper, as with anyone else (Wilson 1930).' Work was good for the patient's health as well as for the colony's economic independence. Wilson added, a 'busy working leper is far happier, and will show better results in treatment, because his circulation, bowels, appetite and general health will be better for the work. From an economic standpoint also there is great saving' (Wilson 1930).

Ernest Muir, Medical Secretary to the British Empire Leprosy Relief Association, also spoke highly of physical training. 'The patient should as far as possible consider himself "in training" as regards exercise, diet and regular habits' (Muir 1938). Without this, no form of treatment would have a long-term effect. Labour and physical exercises were nonetheless only part of this grand training system. According to Muir's plan, the 'efficiently organized leper settlement may act as a model in the area in which it is situated.' Intelligent young patients might be encouraged to undergo training programmes in the detection, treatment, and prevention of leprosy. After their recovery, they could work in treatment centres, or be employed to conduct leprosy surveys and to spread knowledge of public health methods in local communities. 'In this way anti-leprosy measures may embody general sanitary reform, and act as a key to the solution of other problems' (Muir 1938).

Under the circumstances, work and physical exercise were unsurprisingly predominant in the Happy Mount Leprosy Colony. The inmates were constantly engaged in communal work, such as constructing and repairing roads and houses, bush clearing, vegetable growing, and animal farming. ${ }^{19}$ Apart from these forms of public work, occupations and hobbies were also encouraged and designed to fill '[the patients'] lives with interest and if necessary afford them an opportunity of earning some money. ${ }^{20}$ More vegetables, repairing work and basket making meant more health and less operating expenses. Work also kept patients from brooding, as the incidence

\footnotetext{
${ }^{18}$ LMI 118/5, Gushue-Taylor to W. H. P. Anderson, June 4, 1933.

${ }^{19}$ LMI 118/5, George Gushue-Taylor, 'Raku-san-en (Happy Mount Leprosy Colony), Tansui-gun, Formosa, Japan,' News Letter No. 10, February 1937.

${ }^{20}$ Gauld, 'Happy Mount Leprosy Colony-Formosa 1937-1938,' p. 39.

p. Springer
} 
of mental diseases was fairly common in leprosaria. ${ }^{21}$ The regulation of the patient's daily schedule, with a view that both the mind and the body should be kept occupied, was thought to be essential (Muir 1938). Gretta Gauld (吳阿玉) explained her and her mother's work at Happy Mount during Dr. and Mrs. Gushue-Taylor's furlough in 1937-1938: 'Our task was mainly to supervise and keep order, to plan each day's programme so that the patients would be happily occupied in clean wholesome work or recreation to save them from despair, and encourage those afflicted with a nigh incurable disease. ${ }^{, 22}$ The colony was also partly managed according to the principle of local self-government originally envisaged by GushueTaylor. ${ }^{23}$ Under the direction of Pastor Keh (郭水龍), a local missionary, those patients who became elders and deacons learned methods of church government and helped maintain order in the colony. This regimen of regulated occupation seemed effective. Gushue-Taylor observed that work led to 'moral' and 'physical' health (Anonymous 1928).

Apart from its edifying and regenerative values, work fulfilled another function. Gushue-Taylor noted that '[c]onstruction work for the leprosy colony is not only making roads and erecting houses but is literally "preparing the way of the Lord" and making straight in the desert a highway for our God...' (Anonymous 1932a). At Happy Mount, religious and medical discourses became mutually supportive. The analogous relationship between the secular and spiritual life also showed in another facet. The ethics of work, self-reliance and self-government propagated by the medical missionary tallied with the guidelines of the Board of Foreign Mission of the Presbyterian Church. Self-government, self-support, and self-propagation were the three guiding principles for native churches (Mackay 1931; MacMillan 1937a), and only the latter was never the goal of a leprosy colony. This was demonstrated in the segregation of sexes within the institution. By the same logic, the Kingdom of God was actualised in the daily routines of the leprosy colonists as well. The enclosed space of a colony became a field in which a number of innovative designs were put into practice. In contemporary leprosy colonies and asylums, the Western colonizers carried out experiments in administration. Self-government, a practice fairly common amongst leprosy patients, was also the political and social system characteristic of the local communities (Anonymous 1926a; McKean 1932). For instance, the system of 'headmen' or 'chiefs' could be seen in a great number of leprosy colonies in British India and Africa. 'Headmen' were brought into the institutions to maintain discipline, both to instil a sense of responsibility and transform the socially despised into proper 'citizens' (Cooke 1931; McKean 1932). In the above-mentioned Nigerian leprosy colony, the original plan was to segregate patients according to their tribes, but it was never carried out because the inmates worked and played harmoniously together without incident. 'Thus,' Robertson explained, 'the colony is only another agency for amalgamating and bringing under one central government all these hundreds of tribes of Nigeria to make of them some

\footnotetext{
${ }^{21}$ George Gushue-Taylor, 'Happy Mount Leprosy Colony (Rakusanen), Formosa, Japan,' News Letter No. 7. In the $1930 \mathrm{~s}, 19.5 \%$ of the patients of National Leprosarium at Carville, Louisiana, suffered from psychical and nervous complaints. See Muir (1939).

${ }^{22}$ Gauld, 'Happy Mount Leprosy Colony,' p. 42.

${ }^{23}$ LMI 38/16, George Gushue-Taylor, 'Notes on the Appeal to the Government-General of Formosa for Aid to Mission Leper Work' (February 1928), p. 3.
} 
day an independent country able to run their own affairs' (Robertson 1932). In an era when the missionary presence in colonial leprosy work was massive, these secular concerns became part of its philosophy of management. In this sense, missionary leprosy colonies reflected the social and moral orders of the colonial society at large (Vaughan 1991). This logic of correspondence, however, did not apply in all cases. Missionary workers like Gushue-Taylor picked up values and practices specific to certain colonial contexts and translated them to other places.

Just like their fellow patients in colonial India and Africa, after training, suitable inmates at Happy Mount were put in charge of uncomplicated medical care. 'Our aim,' as Gushue-Taylor put it, 'would be to train leper patients in simple medical, dental and nursing work. The ideal in a leper colony is to utilise leper workers and eliminate as far as possible all non-leper help. ${ }^{24}$ What the Canadian doctor envisaged here was more than a self-reliant and self-rehabilitating agricultural colony. Happy Mount and MacKay Memorial Hospital were designed as part of a public health initiative:

Propaganda enlightening the public as to the nature of the disease should be undertaken. Without an enlightened, educated, informed public, it is impossible to enlist that co-operation which is essential if early cases are to present themselves for treatment, and if hiding of such cases is to be prevented. The medical profession should have special training in the diagnosis and treatment of early leprosy (Gushue-Taylor 1929).

Gushue-Taylor wrote and lectured on the curability of leprosy and its prevention. As a result, a number of patients came to MacKay Memorial Hospital and Happy Mount for medical assistance. ${ }^{25}$ For a period of time, doctors from the MacKay Hospital gave treatment to lepers at Ai-ai Ryo on a regular basis. ${ }^{26}$ Robert McClure, a Canadian physician working with Gushue-Taylor in the late 1920s and early 1930s, considered this as 'a workable plan and...a very natural outgrowth to fill the pressing need. ${ }^{, 27}$ Gushue-Taylor and his associates also provided expert knowledge and medications to several local physicians willing to aide their work. ${ }^{28}$

Gushue-Taylor emphasised on several occasions that the colony life was an ordinary, familial one. Work, exercise and education made 'the lives of lepers no different from those in the outside world' (Gushue-Taylor 1934; Anonymous 1928). However, long-term communal life transformed patients from different social and educational backgrounds into a new and highly characteristic community. The active medical intervention did not only change the doctor-patient relation from passive internment to active treatment and discipline, but refashioned the lives of the supervisors and that of the inmates. The whole colony, in its every detail, was turned into a medical and religious environment. Each of its norms and values had therapeutic and cultivating effects.

\footnotetext{
${ }^{24}$ LMI 118/5, George Gushue-Taylor, 'Plans for Leprosy Work in Formosa,' n.d.

${ }^{25}$ LMI 118/5, Robert B. McClure to W. H. P. Anderson, January 16, 1930.

${ }^{26}$ LMI 118/5, Robert B. McClure to W. Hayward, March 14, 1930.

${ }^{27}$ LMI 166/2, Foreign Countries General Book 1902-39, Book I.

${ }^{28}$ 'These are in all cases Formosan doctors...' LMI 118/5, Robert B. McClure to W. H. P. Anderson, June $25,1929$. 
After spending Christmas Eve at Happy Mount in 1935, Rev. Hugh MacMillan (明有德), who had been instrumental from the very beginning in the founding of the colony, was deeply impressed both by the performance of the patients and the 'colony spirit' he witnessed. A female dancer's silk robes, for instance, 'looked like [they were from] New York or Paris under the 60-Watt light manipulated by an electrician-leprous-patient.' MacMillan continued:

Every movement in the whole performance was carried out with mechanical precision. The dummy telephone on the rich man's desk was rung by an old alarm clock somewhere in the patient group. Every step of the dancing girls who performed for Dives while on earth was synchronized as with automatic precision with the tin-pan band playing behind the make-shift screen. Here was a community unified in a common undertaking. Every cog fitted into its adjoining one with clock-work precision. In unity such as this there is strength (MacMillan 1937b).

What was replicated in Happy Mount was not just a vibrant and civilised community with modern convenience. Role-playing went deeper. The bodies of the patients were also trained in a similar modernist fashion, akin to a contemporary factory predicated upon a new sense of time and a spirit of cooperation. Apart from the body, one's identity was refashioned as well in this highly theatrical environment. By following the example of Christ, the medical missionaries were given the mandate not only to heal but to supervise. As in British Africa, patients at Happy Mount were invited to identify with lepers depicted in the Bible (Vaughan 1991). By enacting Pharaoh's daughter, Lazarus, Dives and the Prodigal Son, and by following a regimen of communal work, the previous social outcasts learned to be both model Christians and responsible patients.

These mind-altering and body-remodelling techniques were not introduced for the sole purpose of management. According to the contemporary medical discourse, leprosy was prevalent in the backward areas in which the moral, intellectual, living, hygienic and nutritional conditions were considered poor (Rogers and Muir 1925; Deacon 1996). Promiscuity, totemic systems, and other 'uncivilised' conventions were considered as the main causes of leprosy's persistence (Muir 1940). If leprosy equalled degradation and was associated with unrefined practices, the regular injection of chaulmoogra oil would undoubtedly never be enough. The slow and tedious treatment of this mildly contagious disease hinged on the alteration and management of the patient's daily life. In the case of Happy Mount, work ethics, self-government, punctuality, good public health knowledge, and the so-called 'colony spirit' were all considered medically efficacious and morally, spiritually and culturally uplifting. For Gushue-Taylor and many experts of tropical medicine around the world, the implementation of a civilised mode of life seemed to be the best solution.

In addition, the colony life had a complicated symbolic relationship to the world outside the institution.

The place is laid out as a model village. Each cottage houses four patients, has its own kitchen and own garden utensils, water supply laid on the electric light. The women's quarters are separate from the men's. Water-borne sewage disposal 
plant has been installed and works very efficiently, as can be testified by visitors who are asked to inspect the whole place and who testify to its cleanness. There is ground for agricultural work, which all are encouraged to do according to their ability... The church building is tremendous aid and joy in the colony's life. The basement of the church has dispensary, store-rooms, treatment rooms, pathological laboratory, operation theatre, and staff changing room (Gushue-Taylor 1938).

Happy Mount was not merely a modern medical institution. The fact was obvious to the local Christian community. 'Sowing the seed and tending the plants is done in our institutions - the Mackay Memorial Hospital, the Leprosy Colony, 4 schools, 7 Kindergartens, Churches, preaching halls, and through evangelistic work (Burdick 1934).' The missionary medical work with which Gushue-Taylor was involved was part of a greater network designed to promote contemporary Western Christian civilisation. One has also to put the leprosy colony's highly educational and normative functions in a wider context. As Peter Williams argues, there was a radical change of attitude towards medical missionary work in the second half of the nineteenth century. The desire to save the heathen from eternal damnation was replaced by the attempt to create 'a meaningful present' for the uncivilised. For the Protestants, especially the Scottish Presbyterians, European civilisation was none other than 'an embodied Christianity.' It was, therefore, their duty to spread Christian civilisation to the rest of world. The rising medical profession, with its growing respectability through the process of professionalisation, was accordingly 'a better and more accurate symbol' of their superior civilisation than the clergy (Williams 1982; Porter 2004).

\section{An Alternative Colonial Project?}

For Gushue-Taylor, Happy Mount was a model in another sense. As he put it in his 'Plans for Leprosy Work in Formosa,' '[f]ew Governments in leprosy infected lands are giving adequate treatment for lepers. ${ }^{29}$

We plan a residential leper colony to care for two hundred lepers, which is 5\% of the entire number, hoping that in due course the Government will take care of the remaining $95 \%$. A plan has been drawn up of buildings needed to form a model leper colony. ${ }^{30}$

In reality, Gushue-Taylor's plan complied with the guideline of the Mission to Lepers. 'The institutions of our Mission in China are to a large extent models which national effort may be expected to follow, and it is therefore of great importance that these should maintained and strengthened' (The Mission to Lepers 1934). This kind of model institution, as one of its reports explained, did not 'necessarily mean "model" in the sense of elaborate buildings, but in the sense of meeting the existing needs' (The Mission to Lepers 1934). Gushue-Taylor repeated the idea a few years

\footnotetext{
${ }^{29}$ Gushue-Taylor, 'Plans for Leprosy Work in Formosa.'

${ }^{30} \mathrm{ibid}$

钐 Springer
} 
later: 'It is our duty and privilege to do a sample something to teach the Japanese how to care for the lepers in their midst... ${ }^{31}$ For Gushue-Taylor, and perhaps gradually for his patients, work therapy and its complementary measures in this 'colony within a colony' were employed to criticise the Japanese colonial health policies. His plan of 'voluntary segregation' was also in line with the policy of the British Empire Leprosy Relief Association, the hope of which was to make leprosy settlements and colonies open, caring and attractive so that patients might enter for treatment on a voluntary basis and the stigma of the disease could therefore be significantly reduced (Worboys 2001). Underlining the importance of openness and humanity and the value of work therapy, Gushue-Taylor reckoned that the aim of Happy Mount was to help patients return to society after their symptoms disappeared.

In contrast, all the anti-leprosy programmes put forward by the Japanese Government and the majority of its medical professionals during the period were primarily concerned about compulsory segregation (Hayashi 1935). As the population of leprosy patients in Japan was such that the problem was regarded as a national shame at a time of nationalist and imperialist zeal, compulsory segregation was the government's chosen practice. ${ }^{32}$ The situation was further worsened by the general public's refusal to take back 'cured' leprosy patients into society. The government also failed to adequately educate the public on the matter (Cochrane 1929). As a result, the imperial policy remained strict. In 1930, the Minister of Interior Affairs of the Japanese Government spoke of 20-, 30-, and 50-year plans in eradicating leprosy from Japan proper by means of exclusion. Each plan would cost 37-, 40- and 60-million Yen respectively. Dr Yutaka Kamikawa (上川豐), the superintendent of the government-owned Happy Life Leprosy Hospital, had a similar plan for the Japanese and Formosan patients to expire naturally in a confined environment (Kamikawa 1931, 1937). In their propaganda, the authorities of the Happy Life often stressed the psychological and physical comfort and support they offered to the abject inmates (Anonymous 1932b), rather than the curative possibility of work therapy which Gushue-Taylor was never tired of repeating. This rigid sanitary measure of compulsory segregation was also a way of policing the underclass. For one, initially, the main target of Happy Life was the impoverished (Anonymous 1931c). For another, Oltmans and other foreign missionary workers within the Japanese empire noticed that the Japanese were apprehensive about the attraction country clinics might hold for vagrant leprosy patients (Fletcher 1932; Oltmans 1933). Although increasing manpower and resources were allocated by the government in confining patients, the condition of leprosaria was, at least for some, still unpleasant. According to a local English newspaper in Kobe in the early 1930s,

\footnotetext{
${ }^{31}$ PCC 101-D-31, Gushue-Taylor to James Wilson, January 31, 1934, p. 26.

${ }^{32}$ For another example of the implementation of compulsory segregation by the rising nation state, see (Obregón 2002). It is however not to suggest that all rising nation states adopted the policy of forcible confinement. It will become clear later that Japan's leprosy prevention policy had also to do with her medical system as a whole, especially the state intervention of medical affairs.

Elsewhere, South Africa and Australia in particular, racial and medical segregation usually went along. See Deacon (1994, 1996), Saunders (1989), Bashford and Nugent (2001).
} 
Japanese leprosy institutions were 'dreadful' and 'inadequate,' and the inmates were 'almost entirely confined to the destitute class of leprosy infected people., ${ }^{33}$

It is worth noting that, around the same time, a number of contemporary leprologists came to realise that, 'among backward or uncivilised races in warm and tropical countries,' compulsory segregation, which was recommended since the First International Leprosy Conference in 1897, was now considered infeasible for administrative and financial reasons (Rogers 1931). For example, according to James L. Maxwell, segregation was not possible in 'a more enlightened age,' or 'in a country where the disease is so widely spread over so huge an area as in China (Maxwell 1929). ${ }^{34}$ In British India and Africa, as 'coercion had proved negative, the move to an agricultural colony was made on a voluntary basis, with local leaders being encouraged to persuade any of their people suffering from leprosy to move to one of the leper villages' (Saunders 1989). In addition, as another leprosy worker put it, segregation 'frightens the sufferers, who hide themselves, escape early treatment and allow their contagious leprosy to develop to the stage when it becomes incurable' (Burnet 1931).

Gushue-Taylor shared the same view. In addition to institutional care, he often stressed the importance of the spread of public health knowledge. Without correct public understanding of the nature of leprosy, especially its curability, those who were eventually healed would have to remain social outcasts. For him, social medicine could not work without real enlightenment. In contrast, the Taiwanese newspapers were filled with reports on the social danger posed by lepers, their pathological or even criminal behaviours, and the necessity of confinement. In one of his 1929 letters to William Anderson, Gushue-Taylor mentioned the case of Culion to make his point. The policy of forcible internment did not reduce the number of leprosy patients in the Philippines. The disease was still prevalent there. Referring to Kamikawa's scheme, Gushue-Taylor impatiently remarked that the 'eradication of leprosy does not follow armchair statistical table. ${ }^{35}$ His later prognosis of the leprosy problem under Japanese rule went bleaker: 'I see no probability of leprosy being under adequate control in our neighbourhood within at least two generations. Everything tends to show that it will require at least a century or more..." ${ }^{36}$ Later, he suggested that the '[Japanese] Government responsibility is in the same class as that of the British Government for India's Leper problem, and may be described as a bit of a myth. ${ }^{37}$

\footnotetext{
${ }^{33}$ LMI 118/5, George Gushue-Taylor to W. M. Danner, February 19, 1931.

${ }^{34}$ Although both being medical missionaries working in the Far East, Maxwell and Gushue-Taylor had different views about anti-leprosy work. Maxwell reckoned that, as leprosy was a disease of villages, the best solution to the problem of leprosy in China would be village clinics. See Maxwell (1936). For the history of Western intervention in leprosy in late nineteenth- and early twentieth-century China, see Li (2003), Leung (2003).

${ }^{35}$ LMI 118/5, George Gushue-Taylor to W. H. P. Anderson, March 24, 1929.

${ }^{36}$ LMI 118/5, George Gushue-Taylor to W. M. Danner, February, 1931.

${ }^{37}$ PCC 101-D-31, Gushue-Taylor to James Wilson, January 31, 1934, p. 25. For the British disinterest in leprosy problem in India, see Kakar (1996).
} 
Gushue-Taylor's above comment merits further deliberation. In a conversation regarding colonization, he once told the Provincial Chief of Police that 'I was born in England's oldest colony, Newfoundland, so possibly colonization was in the blood. ${ }^{38}$ As a British colonial subject engaging in his own civilising mission in a Japanese colony, he believed in the advantages which colonialism could bring to the peoples subject to it. Yet his identities as both a medical professional and a missionary made him expected more and have concerns different from those of colonial officials. Armed with his familiarity with the local situation and the international development of medical science and public health measures, he called into question aspects of the Japanese colonial rule. Nevertheless, his criticism was not limited to Japan as a latecomer in the contest for colonial expansion and modernization. The British reluctance to launch a comprehensive colonial antileprosy project also became a target of his attacks. The so-called modern method of medicine on the one hand and the sense of Christian compassion on the other made him intolerant of the situation of leprosy patients in most colonial contexts. Governmental inaction, though a frustrating fact which Gushue-Taylor constantly reiterated, prompted more involvement and interest from the wider public. More importantly, it provided a strong justification for his self-imposed standard-setting efforts.

Gushue-Taylor's plan of laying out a model village and fashioning model citizens, however, did not work entirely according to his plan. Insofar as his relationship with the colonial government was concerned, his plan of combining Mackay outpatient clinic (the majority of cases), Happy Mount (early cases) and the governmental Happy Life Hospital ('burnt-out' or 'arrested' cases) into a coordinated public health network did not interest the colonial authorities. ${ }^{39}$ Nevertheless, Gushue-Taylor's persistence in building a colony did run parallel with that of the colonizers, whose national as well as colonial health policy was to enforce segregation. For instance, in 1939, as the colonial measure of confining all open cases became ever more rigid, outpatient work was reduced to such an extent that only a few non-infective patients were treated. ${ }^{40}$ The government did support Happy Mount with its financial and administrative resources, however, for the Japanese, the leprosy colony was only a $\operatorname{cog}$ in a massive colonial machine. The uniqueness that Gushue-Taylor worked hard to preserve and disseminate was worn down in matter-of-fact governmental statistics. In private, the Canadian doctor criticised the Formosan government for downplaying the importance of Happy Mount in its propaganda. This was, as he lamented, one of the reasons why the leprosy colony had never reached its full capacity of 80 inmates (Gushue-Taylor 1941).

Gushue-Taylor's interaction with both the international charity organisation and religious communities was no less difficult. He was under constant criticism for overstretching the Mission to Lepers as well as local and mother churches. As mentioned above, Gushue-Taylor's plan of building a colony was constantly

\footnotetext{
${ }^{38}$ LMI 118/5, George Gushue-Taylor, 'Happy Mount Leprosy Colony (Rakusanen), Formosa, Japan,' News Letter No. 3, February 1932.

${ }^{39}$ Gushue-Taylor's plan for Taiwan is similar to that proposed by Robert Cochrane for Japan proper. See Cochrane (1929).

${ }^{40}$ LMI 118/5, Gushue-Taylor to Anderson, Konkle and Ross, June 20, 1939.
} 
questioned by William Anderson, who saw the work as the responsibility of the Japanese colonial government and strongly recommended the adoption of the outpatient treatment station system. It is indeed true that 'the medical work is fruitful in opening the door for many to the visible Church of Christ on earth,' and that the MacKay Memorial Hospital was taken seriously by the local community and the colonial government because of its anti-leprosy work, yet Gushue-Taylor's plan for the future Happy Mount was approved by the local mission only after earnest efforts and heated debates. ${ }^{41}$ Both before and after the foundation of the Colony, he attracted criticism from some local and mother church members because of his leprosy work. Apart from the Colony's exact relation to both the MacKay Hospital and the local mission, they questioned whether the donation as well as the resources for the Hospital was improperly allocated to Happy Mount. ${ }^{42}$

As far as the reaction from the local community and the patients were concerned, Gushue-Taylor and his colleagues encountered problems of a different nature. In November 1931, when the colony had been under construction for five months, a group of country gentlemen in neighbouring town of Tamsui launched a protest rally. A counter protest was organised by over 300 locals as a response. The construction continued after governmental intervention. ${ }^{43}$ Because of the local unease, the capacity of the colony was restricted by the government from 200 to 80 inmates. Furthermore, Gushue-Taylor's original thought was only to take in amenable early cases. However, patients 'as a rule continue to work outside as long as they can, and public opinion accompanied by our own sense of Christian compassion compel us to admit many who can never expect again to regain their place in Society. ${ }^{44}$ Very soon the majority of the patients were actually severe cases. ${ }^{45}$ Gushue-Taylor lamented as early as in 1934 that '[e]ven in a land of wealth as the United States, at Carville, La., the early and late are in the same hospital, indicating the difficulty in accomplishing the ideal. ${ }^{46}$ Finally, not everyone was keen on a colony system that originated from British India and Africa. Gushue-Taylor, whose overall description of local patients and whose public health policies tended not to be characteristically racist and patronising, nevertheless complained about the '[i]ndolence among patients, grousing, gambling, and other ills [which] tend to sap one's strength., ${ }^{47}$ Work and exercise had never been popular. 'Without the incentive of financial reward,' he explained, 'we could not get the work done: the profit motive rules here

\footnotetext{
${ }^{41}$ LMI 118/5, A. Oltmans to W. M. Danner, March 15, 1929; PCC 101-D-1, Lillian R. Dickson to A. S. Grant, December 15, 1928.

${ }^{42}$ PCC 101-D-31, Presbyterian Church in Taiwan, Canadian General Assembly Committee. Re: Formosa. September 11, 1933. PCC 101-D-2, Presbyterian Church in Taiwan, North Formosa Mission Council Minutes, February 7, 1935.

${ }^{43}$ LMI 118/5, George Gushue-Taylor, 'Happy Mount Leprosy Colony (Rakusanen), Formosa, Japan,' News Letter No. 3, February 1932.

${ }^{44}$ LMI 118/5, George Gushue-Taylor, 'Raku-san-en (Happy Mount Leprosy Colony), Tansui-gun, Formosa, Japan,' News Letter No. 10, February 1937.

${ }^{45}$ LMI 118/5, George Gushue-Taylor, 'Raku-san-en (Happy Mount Leprosy Colony), Tansui-gun, Formosa, Japan,' News Letter No. 14, February 1940, p. 47.

${ }^{46}$ LMI 118/5, George Gushue-Taylor, 'Happy Mount Leprosy Colony (Rakusanen), Formosa, Japan,' News Letter No. 6, May 1934, p. 2.

${ }^{47}$ LMI 118/5, George Gushue-Taylor to W. H. P. Anderson, April 7, 1936.

型 Springer
} 
as well as with the majority of outside well folk.' In 1939, two well-off inmates, one of whom was a Christian and the head patient, instigated 14 other patients to leave Happy Mount and move into the governmental leprosy hospital. According to Gushue-Taylor, the reason for this unfortunate incident was mainly their objection to physical work.

The difficulty we have to contend with is that the institution to which they go do not expect them to do this kind of work and are able to give them more in the way of regular clothing, soap, etc., and are not so strict as we are in the matter of segregation of the sexes, all of which make a combination difficult for us to compete with. ${ }^{48}$

These patients 'were admitted to the government leprosy hospital where work is on a voluntary basis, and where in fact the patients are so numerous (over six hundred) that there is no sufficient work for all to have a share...,49

Previous studies on the history of leprosy tend to focus on colonial and missionary activities and their ideological and psychological implications (Vaughan 1991; Deacon 1996; Anderson 1998; Worboys 2001). The actual extent of the effect of these projects - whether in regard to public health or the construction of colonial subjects - is yet to be explored. For one, in the governmental Happy Life Leprosy Hospital, where discipline was supposedly to be stricter and resources were less constrained than Happy Mount, inmates were much more unruly, at least in the eyes of the authorities. Gambling and leaving the hospital without permission were the two commonest offences. ${ }^{50}$ Similarly, although the alternative colonial project formulated by Gushue-Taylor concerning leprosy prevention seems ideal or even faultless in its own way, a different picture emerges from his reports and correspondence. Inmates' refusal to comply with the requirement to work illustrates the case very well. The spirit of full self-government, which Gushue-Taylor deemed a major principle upon which the colony was to be managed, did not guarantee that the institution could run smoothly. The spirit of a new community did not change the pattern of life to which some patients were accustomed. The Christian identity and semi-citizenship they recently acquired did not entail that the ethics of work could also be transferred with ease. Similar to their fellow patients in India, the Philippines, Columbia, and even Japan proper, not all patients at Happy Mount were passive recipients of modern medicine and its accompanying practices (Anonymous 1937; Kakar 1996; Anderson 1998; Obregón 2002).

\section{Conclusion}

It would be an exaggeration to say that Gushue-Taylor's model-building plan was a great success. Nevertheless, apart from pressuring the Japanese colonial government

\footnotetext{
${ }^{48}$ LMI 118/5, George Gushue-Taylor to Ross, September 23, 1936.

${ }^{49}$ Gushue-Taylor, 'Raku-san-en (Happy Mount Leprosy Colony), Tansui-gun, Formosa, Japan,' News Letter No. 14.

${ }^{50}$ See Lo Sheng Hospital Archives.
} 
to take more serious measures in tackling leprosy, the Canadian doctor's work does tell us something interesting about the relation between medicine and society in colonial Taiwan. Especially, we are better informed about the roles which Western missionary medicine played under Japanese rule, the special form it might take, and, more generally, the efficiency of the Japanese colonial public health service.

In his study of the work of the British Empire Leprosy Relief Association in the first half of the twentieth century, Michael Worboys arrives at an instructive conclusion. Whereas the study in imperial tropical medicine tends to stress the power and consequences of public health measures, the research of regional and specialinterest religious agencies brings to the forefront the connections between missionary humanism, modernisation, and Christian caring (Worboys 2001). At the MacKay leprosy dispensary, leaflets on personal hygiene were distributed as part of the gospel message. ${ }^{51}$ A gesture of this kind is a telling reminder of the nature of Gushue-Taylor's leprosy work. At a time when the Japanese were suspicious of any foreign influence within their empire, the Canadian leprologist and his colleagues' work was not to facilitate colonial domination and exploitation, but to legitimise and reinforce the Western presence in a Japanese colony through the evangelical use of medicine. Instead of 'imperial kindness' or 'imperial benevolence,' Gushue-Taylor spoke of 'our Lord's command' to 'cleanse the leper' and 'modern methods' in combating the disease. Rather than planning a series of steps in producing 'selfpossessed, disciplined colonial (and protonational) subjects' as in the American Philippines (Anderson 1998), he wished to bring up self-governing, self-reliant, selfregenerative but no less self-possessed modern world citizens in this tiny enclave. Willingness to volunteer, a good work ethic, the so-called colony spirit, and the presupposed universal standard of modern Western civilisation were all keys to this idealistic project. This global citizenship with a strong religious flavour was one of Gushue-Talyor's ways to question the Japanese policy of confining all leprosy patients. Unfortunately, as a result of the colonial government's steadfastness at enforcing compulsory segregation and of the poor outcome of the chaulmoogra oil treatment, the alternatives in public health, medical practices and colonial subject formation that he worked hard to offer the local government and community consequently had little appeal. ${ }^{52}$

Warwick Anderson and others have argued that it is imperative to rewrite previous nation-centred histories in both science and medicine. One would be better served looking into the ways in which bodies of knowledge, products, and technologies travelled (Anderson 2002). Gushue-Taylor's work is a fine example of this exchange of ideas and practices. Long before Happy Mount was ever open, plans for several different types of leper-homes in India, China and other countries were made available to Gushue-Taylor. ${ }^{53}$ Sometimes assigned as a member of the

\footnotetext{
${ }^{51}$ Gushue-Taylor, 'Leprosy in Formosa'; Gushue-Taylor, 'The Year's Work at Taihoku, Formosa,' p. 51.

${ }^{52}$ It is imaginable that similar projects initiated by Western missionaries could be found in Korea and Japan proper around the same time. Nevertheless, in order to have a bigger picture of missionary leprosy works and their actual impacts within the Japanese Empire as a whole, more comparative studies are clearly called for.

${ }^{53}$ LMI 38/16, Henry Folwer to Gushue-Taylor, October 28, 1925; LMI 118/5 W. H. P. Anderson to A. E. Armstrong, January 8, 1926.
} 
Staff on Special Duty attached to 'the Encyclopaedic Section of the GovernmentGeneral's Cabinet' (總督府官房調查課), ${ }^{54}$ the Canadian leprologist travelled widely. For instance, from March 1929 to March 1930, he went on a fundraising and study tour. 'The itinerary followed was Formosa, Kobe, Japan; Hawaii, Honolulu and Molokai; San Francisco, Los Angeles, Carville, Louisiana, New York; Ontario, Newfoundland; England, Scotland, India, Formosa (Gushue-Taylor 1930).' GushueTaylor acted as the Secretary to the Leonard Wood Memorial Conference on Leprosy in Manila in early 1931 and visited the famous leprosy colony Culion (Anonymous 1931b). In 1937, he briefly studied at the School of Tropical Medicine in London, and participated as the Formosan delegate in the International Leprosy Conference in Cairo the following year (MacMillan 1939). His participation in such activities clearly shows that the specificity of Happy Mount can only be understood by taking into account missionary activities in other parts of the world and the transformation of anti-leprosy policies on a truly international scale. ${ }^{55}$

During a time when the terminology, classification and treatment of leprosy varied widely, contemporary leprologists around the world also underlined the importance of arriving at 'a certain degree of standardization' for clinical and statistical purposes (Burnet 1931). This tension between regional uniqueness and standardization gave rise to Happy Mount's specific form. Gushue-Taylor's work was that of transmission, translating some of the Western colonial experience for a Japanese dependency. Happy Mount was never an exact replicate of the British Indian and African or American/Philippine system; the Canadian doctor worked out his own plan for controlling leprosy. Even though no signs of reciprocal traffic of ideas and methods can be found between Happy Mount and other foreign institutions, colonial medical knowledge and methods originating from multiple sites were selectively adapted to meet the specific needs of the Taiwanese society. ${ }^{56}$ The leprosy colony was also not just built by a few foreign missionaries of surpassing integrity alone; rather, it was the end product of both international and local outputs. Without direct metropolitan support as the Japanese medical professionals or other missionaries in Colonial India and Africa, Gushue-Taylor's work was inevitably eclectic. He had to resort to receiving aid from any possible source-be it fellow Christians, international charity organisations, local people, or the Japanese colonial government. Finally, the way in which Happy Mount actually operated changed constantly, brought forth by the mediations between: the international charity organisation, the Japanese colonial government, local and mother churches, patients, the local community, medical missionaries, and the disease with its changing conceptualisations and treatments.

\footnotetext{
${ }^{54}$ LMI $118 / 5$, n.d.

${ }^{55}$ 'It is deemed highly advisable that any country or institution undertaking serious work in leprosy should send some of its leading workers to one or more of the main centers of leprosy activities, in order to study the local conditions and the methods in use. The value of this lies not only in the knowledge acquired that can be applied directly to the visitor's own work, but also in the broadening of his outlook on the leprosy problem as a whole' (Anonymous 1931b). It is interesting to note that the Japanese government, while frequently sending delegates and specialists to international conferences and places like Dutch India to survey anti-leprosy work, stuck to its original system of paternalist and centralized control even in the post-war period.

${ }^{56}$ For the critique of the diffusionist version of scientific development, see Palladino and Worboys (1993).
} 
As Mark Harrison pointed out, the study of a chronic disease like leprosy helps us bypass the untypical incidents of epidemics and look into the daily experiences of patients and medical practitioners in the colonial context (Harrison 2002). Gushue-Taylor's criticism of the colonial leprosy policy therefore provides an excellent opportunity to reconsider the traditional image of an efficient and pervasive Japanese public health system during the colonial period. A more nuanced picture emerges. For instance, the number of patients confined within the Happy Life Hospital a decade after its opening did not ever exceed 800 - clearly demonstrating a medical incarceration rate far below acceptable medical standards. The main purpose of the present study is, however, not to use a foreign medical missionary's comments to criticise the Japanese colonial rule. As regional diversity in leprosy work around the world was quite common during the colonial era, the conflict between different public health practices should be put into its historical context. Megan Vaughan rightly suggests that, while missionary workers were more interested in individual care and treatment, colonial governments were primarily concerned with 'disease agents, vectors, and populations' (Vaughan 1991). Shiyung Liu also reminds us that, as the Japanese public health system was primarily a centralised and top-down one, medical resources were supposedly to be allocated efficiently and evenly within the whole society (Liu 1999, 2001). The fact that Happy Life Hospital remained the only special governmental institution catering for the need of Japanese and Taiwanese leprosy patients on the island during the whole colonial period is highly symbolic. A monolithic and yet ill-equipped governmental leprosarium combined with a reporting system manned by a local police force, administrative officers of the districts, and physicians was Japan's answer to the leprosy problem in Taiwan, their so-called 'model colony.' In the eyes of a well-informed missionary physician supported by a charitable special-interest organization with global experience, the Japanese programme could only reasonably be viewed as slow, ineffective, and ultimately inadequate.

Though not a great success in many ways as Gushue-Taylor had envisioned it, the colony was indeed transformative for some of its members. Regarding a 17-year-old patient's discharge, Dr Lee (李達莊) of Happy Mount gave him 'parting instructions about continuing his life as he had learned to live at Happy Mount...simple, nourishing food, fresh air, exercise, work, sleep, his spiritual life. He will return in 3 months for the doctor to look him over again (MacMillan 1938).' Some of the less fortunate were no less dispirited. An elderly male patient once told Gretta Gauld that '[i]f I hadn't become a leper...I should never have heard the Gospel. Though my skin is diseased, my heart has been cleansed through Christ. It was worth while being afflicted to win such a blessing. ${ }^{57}$ With the spread of colonial medicine and the missionary involvement in it, this unique and personal experience seemed likely to turn into a somewhat universal one. As the Mission to Lepers recorded in the history of its organisation in 1934, "“[i]t is worth while being a leper," remarked a man at Chitokoloki, "because by being a leper I have come to know the Saviour" - a statement that has been heard many times in our other Homes in India and elsewhere' (The Mission to Lepers 1934). ${ }^{58}$

\footnotetext{
${ }^{57}$ Gauld, 'Living with Lepers at Rakusanen,' p. 155.

${ }^{58}$ Chitokoloki is a missionary medical station in Zambezi, Zambia.

Springer
} 
Acknowledgements I am grateful to Daiwie Fu, Ping-Yi Chu, Chia-Ling Wu and Sean Hsiang-Lin Lei for their comments on previous drafts of this article. My thanks also to two referees for very valuable suggestions. Part of the research undertaken was sponsored by the National Science Council, Taiwan (NSC 95-2411-H-305-004).

\section{References}

Anderson, W. (1998). Leprosy and citizenship. Positions, 6.3, 707-730.

Anderson, W. (2002). Postcolonial technoscience. Social Studies of Science, 5/6, 643-658.

Anonymous (1920). Chien laipingyuan 建癩病院. Taiwan nichinichi shimpoo 臺灣日日新報, August 3, 1920.

Anonymous (1926a). South Africa: Self-government in a leper institution. The Lancet, 207, 44 (January).

Anonymous (1926b). Lainientu hsinchihua lailiaoyangso neijung 來年度新計畫 癩療養所內容. Taiwan nichinichi shimpoo 臺灣日日新報, December 25, 1926.

Anonymous (1928). 'Sha kai ji gyo ko ro sha no ryaku reki oyobi sho kan' 社會事業功勞者の略歷及所 感. Sha kai ji gyo no to mo 社會事業の友, 2, 89.

Anonymous (1930). Aiailiao tsengchu locheng chingshen pingche ke chito 愛愛寮增築落成 精神病者可 寄託. Taiwan nichinichi shimpoo 臺灣日日新報, June 13, 1930.

Anonymous (1931a). Kan ko rithu rai ryo yo jyo no ithi ran 官公立癩療養所一覽. Sha kai ji gyo no to $m o$ 社會事業の友, 27, 213-214.

Anonymous (1931b). Report of the Leonard Wood Memorial Conference on Leprosy. The Philippine Journal of Science, 44.4, 449-480.

Anonymous (1931c). Tainan laijen erhshihchiu ming ju taipei leshengyuan 臺南癩病人二十九名入臺北 樂生院. Taiwan nichinichi shimpoo 臺灣日日新報, January 23, 1931.

Anonymous (1932a). Happy mount leprosy colony. The Presbyterian Record, 114-115 (April).

Anonymous (1932b). Lesheng yuan yuanchang shangchuan poshih tan laiping chihliaoso chih chingkuo chi lai wei chungping chung tsui wei kepu che 樂生院長上川博士談癩病治療所之經過及癩為眾病 中最為可怖者. Taiwan nichinichi shimpoo 臺灣日日新報, October 18, 1932.

Anonymous (1937). Lepers on strike in Japan. Leprosy Review, 8.1, 48-49.

Aoki, T. 青木大勇 (1901). 'Raiin sekti no hitsuyō wo ronzu’ 癩院設置の必要を論ず. Taiwan iji zaksi 臺灣醫事雜誌, 3.6/7, 1-10.

Arnold, D. (1994). Crisis and contradiction in India's public health. In D. Porter (Ed.), The history of public health and the modern state (pp. 335-355). Amsterdam: GA Editions Rodopi B. V.

Bashford, A., \& Nugent, M. (2001). Leprosy and the management of race, sexuality and nation in tropical Australia. In A. Bashford \& C. Hooker (Eds.), Contagion: Historical and cultural studies (pp. 106128). London: Routledge.

Bernabeu-Mestre, J., \& Ballester-Artigues, T. (2004). Disease as a metaphorical resource: The fontilles philanthropic initiative in the fight against leprosy, 1901-1932. Social History of Medicine, 17.3, $409-421$.

Burdick, A. (1934). Our Formosa garden. The Glad Tidings, 10.9, 312-313.

Burnet, E. (1931). The league of nations and the fight against leprosy. Leprosy Review, 2.4, 122-129.

Chen, H.-Y. 陳歆怡 (2005). Chienyu huo chia? Taiwan mafeng huanche te keli shengya yu tzuwo chungchien 監獄或家? 台灣㾁瘋病患者的隔離生涯與自我重建. MA Dissertation, National Tsing Hua University.

Chen, W.-B. 陳威彬 (2001). Chintai taiwan te laiping yu liaoyang: Yi lesheng liaoyangyuan wei chuchou 近代臺灣的癩病與療養: 以樂生療養院為主軸. MA Dissertation, National Tsing Hua University.

Cochrane, R. G. (1929). Leprosy in the Far East (p. 8, 16). London: World Dominion Press.

Cochrane, R. G. (1934). Progress in treatment for leprosy 1924-1934. In The Mission to Lepers, sixty years of service 1874-1934 (pp. 73-79). London: Mission to Lepers.

Cooke, F. H. (1931). History of the Ho Leper settlement. Leprosy Review, 2.1, 8-11.

Deacon, H. (1994). Leprosy and racism at Robben Island. In E. van Heyningen (Ed.), Studies in the history of Cape Town (Vol. 7, pp. 45-83). Cape Town: University of Cape Town.

Deacon, H. (1996). Racial segregation and medical discourse in nineteenth-century Cape Town. Journal of Southern African Studies, 22.2, 287-308.

Fann, Y.-C. 范燕秋 (2001). 'Jihpen tikuo fachan hsia chihminti Taiwan te jenchung weisheng (18951945)’ 日本帝國發展下殖民地台灣的人種衛生 (1895-1945). PhD dissertation, National Chengchi University. 
Fann, Y.-C. 范燕秋 (2005). Chintai taiwan te laiping liaoyang yu yipping keli kungchien 近代台灣 的癩病療養與疫病隔離空間. In Yiping yihsueh yu chihmin hsientaihsing 疫病、醫學與殖民現 代性：日治台灣醫學史 (pp. 179-227). Taipei: Taohsiang.

Fletcher, A. G. (1932). Country clinics or dispensaries for treatment of cases of leprosy. Leprosy Review, $3.2,58-66$.

Fu, D. 傅大為 (2005). Yahsiya te hsin shenti 亞細亞的新身體. Taipei: Socio.

Gauld, G., \& Gauld, G. (1939). Living with Lepers at Rakusanen. The Glad Tidings, 15.4, 154-158.

Gushue-Taylor, G. (1929). Leprosy in Formosa. China Medical Journal, 43.1, 4-12.

Gushue-Taylor, G. (1930). Happy Mount Leprosy Colony, Formosa, Japan. News Letter No. 1 (November).

Gushue-Taylor, G. ジー・グシウ・テイラー (1934). 'Raku san en no ji gyo to so no zen to' 樂山園の 事業と其の前途. Sha kai ji gyo no to mo 社會事業の友, 67, 21.

Gushue-Taylor, G. (1938). If thou wilt thou canst make me clean. The Glad Tidings, 14.5, 194-197.

Gushue-Taylor, G. (1941). Raku-san-en (Happy mount leprosy colony). Tansui-gun, Formosa, Japan News Letter No. 15, March 1941. The Glad Tidings, 17.4, 149-152.

Gushue-Taylor, G. (1984). Taijenshou poshih chih taiwan laiping chiuchihhui han erh (24 June 1931) 戴仁壽博士致臺灣癩病救治會函二 (24 June 1931) (1984). Leshanwushih 樂山五十. Taipei: Happy Mount Sanatorium.

Gussow, Z. (1989). Leprosy, racism, and public health: Social policy and chronic disease control. Boulder: Westview.

Gussow, Z., \& Tracy, G. S. (1970). Stigma and the leprosy phenomenon: The social history of a disease in the nineteenth and twentieth centuries. Bulletin of the History of Medicine, 44, 435-449.

Harrison, M. (2002). Book review of leprosy in colonial South India: Medicine and confinement (Jane Buckingham), http://www.history.ac.uk/ihr/Focus/Empire/reviews/harrison.html.

Hayashi, F. (1935). Report of a leprosy study tour. International Journal of Leprosy, 3.2, 165-180.

Ishii, T. 石井保 (1931). ‘Tai wan ni okeru rai ni tsuite’ 臺灣に於けろ癩に就て. Sha kai ji gyo no to mo 社會事業の友, 27, 6-10.

Kakar, S. (1996). Leprosy in British India, 1860-1940: Colonial politics and missionary medicine. Medical History, 40, 215-230.

Kamikawa, Y. 上川豐 (1931). Rai yo bo kon zethu ji gyo to sha kai teki un do 癩豫防根絕事業と社會的 運動. Sha kai ji gyo no to mo 社會事業の友, 27, 112-121.

Kamikawa, Y. 上川豐 (1937). Tai wan no rai kyu sai kon zetu kei kaku an 臺灣の癩救濟根絕計畫案. Sha kai ji gyo no to mo 社會事業の友, 100, 44-61.

Kato, U. 加藤卯吉 (1935). Tai wan yo bo e sei gai kan 臺灣豫防衛生视觀. Taihoku: GovernmentGeneral of Taiwan.

Kerr, G. M. (1937). The organization of occupational therapy. Leprosy Review, 8.2, 64-69.

Kipp, R. S. (1994). The evangelical uses of leprosy. Social Science and Medicine, 39.2, 165-178.

Leung, A. K. C. 梁其姿 (2003). Mafeng keli yu chintai chungkuo 痄瘋隔離與近代中國. Lishih yuchiu 歷史研究, 5, 3-14.

Li, S.-J. 李尚仁 (2003). 'Shihchiu shihchi houchi yingkuo yihsuehchieh tui chungkuo mafeng pingching te tiaocha yuchiu’十九世紀後期英國醫學界對中國痳瘋病情的調查研究. Bulletin of the Institute of History and Philology Academia Sinica 中央研究院歷史語言研究所集刊, 74.3, 445-506.

Li, T.-Y. 李騰获 (1972). Taiwansheng tungchihkao, chengshihchih weishengpien 臺灣省通誌政事志衛 生篇下 (Vol. 2). Taipei: Taiwansheng wenchienhui.

Liu, S. 劉士永 (1999). Yichiusanling nientai yichien jihchih shihchi taiwan yihsueh te techih 一九三○年 代以前日治時期臺灣醫學的特質. Taiwan Historical Research 臺灣史研究, 4.1, 97-148.

Liu, S. 劉士永 (2001). Chingchieh, weisheng yu paochien「清潔」，「衛生」與「保健」一日治時期 臺灣社會公共衛生觀念之轉變. Taiwan Historical Research 臺灣史研究, 8.1, 41-88.

Liu, S. (2004). Building a strong and healthy empire: The critical period of building colonial medicine in Taiwan. Japanese Studies, 24.3, 301-314.

Lo, M.-C. (2002). Doctors within borders: Profession, ethnicity and modernity in colonial Taiwan. Berkeley: University of California Press.

Mackay, G. (1931). News. The Glad Tiding, 7.1, 9.

MacMillan, H. (1937a). The second Formosan ministers' conference. The Presbyterian Record, 368-370 (December).

MacMillan, H. (1937b). Rakusanen, "Happy Mount Leprosy Colony," Formosa, Japan. News Letter No. 11 (Christmas).

MacMillan, H. (1938). Happy Mount Leprosy Colony, Formosa. The Presbyterian Record, 120 (April).

MacMillan, H. (1939). Happy Mount Leprosy Colony. A Circular Letter by Rev. High MacMillan. The Presbyterian Record, 49-50 (February). 
Maxwell, J. L. (1929). The diseases of China, including Formosa and Korea (2nd ed., p. 84). Shanghai: ABC Press.

Maxwell, J. L. (1936). The fight against leprosy. Chinese Medical Journal, 50.5, 742-743.

McKean, J. H. (1932). The place of local self-government in leprosy home administration. Leprosy Review, 3.3, 105-107.

Miyahara, A. 宮原敦 (1919). Tai wan no rai jin 臺灣ノ癩人. Taiwan igakkai zasshi 臺灣醫學會雜誌, 201, 734-806.

Miyahara, A. 宮原敦 (1921). Rai no thi ryo rei 癩ノ治療例. Taiwan igakkai zasshi 臺灣醫學會雜誌, 219, 592-598.

Muir, E. (1936). Prognosis in leprosy I. The Lancet, 228, 391-392 (August 15).

Muir, E. (1938). Leprosy: Diagnosis, treatment and prevention (6th ed., p. 164). Delhi: The Indian Council of the British Empire Leprosy Relief Association.

Muir, E. (1939). Some mental aspects of leprosy. Leprosy Review, 10.2, 114-118.

Muir, E. (1940). The leprosy situation in Africa. Journal of the Royal African Society, 39.155, 134-142.

Nakamura, H. 中村不羈兒 (1931). Tai wan ni rairyōyōsho no sekiti seraru made 臺灣に癩療養所の設置 せらるろまで. Sha kai ji gyo no to mo 社會事業の友, 27, 149-158.

Obregón, D. (2002). Building national medicine: Leprosy and power in Colombia, 1870-1910. Social History of Medicine, 15.1, 89-108.

Oltmans, A. (1933). Anti-leprosy movements in Japan. Leprosy Review, 4.2, 82-88.

Palladino, P., \& Worboys, M. (1993). Science and imperialism. Isis, 84, 91-102.

Pan, P.-C. 潘佩君 (2005). Lesheng liaoyangyuan yuanming mientui panchien chengtse te chutihsing yenchiu 樂生療飬院院民面對搬遷政策的主體性研究. MSc Dissertation, National Yang Ming University.

Porter, A. (2004). Religion versus Empire: British protestant missionaries and overseas expanison, 17001914. Manchester: Manchester University Press.

Robertson, R. L. (1932). Garkida agricultural-industrial leprosy colony. Leprosy Review 3.2, 50-58.

Rogers, L. (1931). Memorandum on the present position of prophylaxis against leprosy in relation to recent improvement in treatment. Leprosy Review, 2.3, 102-109.

Rogers, L., \& Muir, E. (1925). Leprosy. New York: William Wood and Company.

Roland, C. G. (1996). George Gushue-Taylor and the medical missions in Formosa. Journal of Medical Biography, 4, 82-93.

Sato, H., \& Narita, M. (2003). Politics of leprosy segregation in Japan: The emergence, transformation and abolition of the patient segregation policy. Social Science \& Medicine, 56, 2529-2539.

Saunders, S. (1989). 'A suitable island site': Leprosy in the northern territory and the channel island leprosarium, 1880-1955. Darwin: Historical Society of the Northern Territory.

Serizawa, R. 芹澤良子 (2006). Jihchih shihchi taiwan laiping fangchih chengtse te fachan 日治時期臺灣 癩病防治政策的發展. In Taiwan Historica (Ed.), Tissuchieh taiwan tsungtoufu tanan hsuehshu yentaohui lunwenchi 第四屆臺灣總督府案學術研討會論文集 (pp. 223-243). Nantou: Taiwan Historica.

The Mission to Lepers (1934). Sixty years of service 1874-1934. London: The Mission to Lepers.

The Leprosy Mission (1974). This spreading tree: The story of the leprosy mission from 1918 to 1970. London: The Leprosy Mission.

Vaughan, M. (1991). Curing their ills: Colonial power and African illness. Stanford: Stanford University Press.

Williams, C. P. (1982). Healing and Evangelism: The place of medicine in later victorian protestant missionary thinking. In W. J. Sheils (Ed.), The church and healing (pp. 271-285). Oxford: Basil Blackwell.

Wilson, R. M. (1930). Industrial therapy in leprosy. Leprosy Review, 1.1, 25-28.

Worboys, M. (2001). The colonial world as mission and mandate: Leprosy and empire, 1900-1940. Osiris, 15, 207-218.

Yen, L.-Y. 顏亮一 (2005). Chuanchiuhua shihtai te wenhua yichan: Kuchi paochun lilun chih pipanhsing huiku 全球化時代的文化遺產：古蹟保存理論之批判性回顧. Journal of Geographical Science 地理學報, 42, 1-24. 